\title{
Environmental radiofrequency radiation at the Järntorget Square in Stockholm Old Town, Sweden in May, 2018 compared with results on brain and heart tumour risks in rats exposed to $1.8 \mathrm{GHz}$ base station environmental emissions
}

\author{
LENNART HARDELL ${ }^{1,2}$, MICHAEL CARLBERG ${ }^{1,2}$, LENA K. HEDENDAHL $^{2}$, \\ TARMO KOPPEL ${ }^{3}$ and MIKKO AHONEN ${ }^{4}$ \\ ${ }^{1}$ Department of Oncology, Faculty of Medicine and Health, Örebro University, SE-701 82 Örebro; \\ ${ }^{2}$ The Environment and Cancer Research Foundation, SE-702 17, Örebro, Sweden; \\ ${ }^{3}$ Department of Labour Environment and Safety, Tallinn University of Technology, 19086 Tallinn; \\ ${ }^{4}$ Institute of Environmental Health and Safety, 11615 Tallinn, Estonia
}

Received October 30, 2018; Accepted November 29, 2018

DOI: $10.3892 /$ wasj.2018.5

\begin{abstract}
Radiofrequency (RF) radiation in the frequency range $30 \mathrm{kHz}$ to $300 \mathrm{GHz}$ was evaluated in 2011 by the International Agency for Research on Cancer (IARC) at WHO to be a 'possible human carcinogen' Group 2B. The conclusion was based on human epidemiological studies on an increased risk of glioma and acoustic neuroma. In previous measurement studies, we found high environmental RF radiation levels at certain public places and also in an apartment in Stockholm, Sweden. One such place was the Järntorget square in the Stockholm Old Town. The EME Spy exposimeter was used for these studies. We have now conducted a field spatial distribution measurement with a radiofrequency broadband analyser. The maximum E-field topped at $11.6 \mathrm{~V} / \mathrm{m}$ at the centre of the square, where the antenna was focused. Järntorget's mean value was $5.2 \mathrm{~V} / \mathrm{m}$, median $5.0 \mathrm{~V} / \mathrm{m}$, range $1.2-11.6 \mathrm{~V} / \mathrm{m}$. Of interest is that this level can be compared to a lifespan carcinogenicity study on rats exposed to $1.8 \mathrm{GHz}$ GSM environmental radiation performed at the Ramazzini Institute (RI) in Italy. A statistically significant increase in the incidence of malignant schwannoma in the heart was found in male rats at the highest dose, $50 \mathrm{~V} / \mathrm{m}$. In treated female rats at the highest dose, the incidence of malignant glial tumours was increased, although this was not statistically significant. On the whole, the findings of this study showed that RF radiation levels at one square,
\end{abstract}

Correspondence to: Professor Lennart Hardell, Present address: The Environment and Cancer Research Foundation, Studievägen 35, SE 70217 Örebro, Sweden

E-mail: lennart.hardell@environmentandcancer.com

Key words: radiofrequency radiation, microwaves, measurement, base stations, exposure, health, cancer
Järntorget, in Sweden, were only one order of magnitude lower than those showing an increased incidence of tumours in the RI animal study. An increased cancer risk cannot be excluded for those working in the proximity of Järntorget for longer time periods.

\section{Introduction}

Radiofrequency (RF) radiation from wireless devices, such as mobile and cordless phones, base stations, and so on in the frequency range $30 \mathrm{kHz}$ to $300 \mathrm{GHz}$ was classified in 2011, as a 'possible human carcinogen' Group 2B by the International Agency for Research on Cancer (IARC), a part of WHO $(1,2)$. In spite of that evaluation, little or mostly nothing has been done to inform and protect the population from RF radiation $(3,4)$. On the contrary, human exposure has increased rapidly in recent years and will increase substantially with the introduction of the fifth generation $(5 \mathrm{G})$ for wireless communication (5-7).

Of special concern is the involuntary environmental exposure to RF radiation. This is the situation in most places with few or no possibilities to avoid exposure. Thus, RF radiation should by now be regarded as environmental pollution that is hard to detect using our senses.

Previously, we reported RF radiation levels in different places in Stockholm in Sweden, such as at the Central Railway station (8), the Old Town (9), in an apartment close to base stations (10) and in the City (11).

High ambient exposure was found at several places, and particularly at the Järntorget square in the Old Town, that was measured in April, 2016 [mean, 24,277.1 $\mu \mathrm{W} / \mathrm{m}^{2}$ (3.03 V/m); median, $19,990.0 \mu \mathrm{W} / \mathrm{m}^{2}(2.75 \mathrm{~V} / \mathrm{m})$; ranging from $257.0 \mu \mathrm{W} / \mathrm{m}^{2}$ $(0.31 \mathrm{~V} / \mathrm{m})$ to $\left.173,301.8 \mu \mathrm{W} / \mathrm{m}^{2}(8.08 \mathrm{~V} / \mathrm{m})\right](9)$.

Recently, the US National Toxicology Program (NTP) released results from their large animal two-year study on cell phone RF radiation exposure $(12,13)$ that we have discussed in further detail elsewhere (14). A statistically significant 
increased risk was found for brain glioma and malignant schwannoma in heart nerves, but also in other organs. There was some evidence of an increased risk of thyroid cancer, and clear evidence that RF radiation is a multi-site carcinogen (14). These results are similar to those found in human epidemiological studies, as reviewed elsewhere $(7,15,16)$.

In the study by the Ramazzini Institute (RI) in Italy, rats were exposed from prenatal life until natural death to a 1.8 $\mathrm{GHz}$ GSM far field of $0,5,25,50 \mathrm{~V} / \mathrm{m}$ with a whole-body exposure for $19 \mathrm{~h}$ /day similar to that from base stations. Increased incidence of similar tumour types that have been associated in individuals using wireless phones were found (17). Thus, a statistically significant increase in the incidence of malignant schwannoma in the heart was found in male rats at the highest dose, $50 \mathrm{~V} / \mathrm{m}$. An increased incidence of heart Schwann cell hyperplasia was observed in the treated male and female rats at the highest dose $(50 \mathrm{~V} / \mathrm{m})$, but was not statistically significant. In treated female rats at the highest dose $(50 \mathrm{~V} / \mathrm{m})$, the incidence of malignant glial tumours was increased, although this was not statistically significant.

The aim of this study was to make additional measurements at Järntorget in Stockholm Old city (Fig. 1) and to compare the levels with the results from the RI study (17). This was a measurement study with no involvement of test persons. Thus, no ethical permission was required.

\section{Materials and methods}

Study design. Field spatial distribution measurements were conducted with a radiofrequency broadband analyser. The square was covered with spot measurements, whereas in each spot the field was measured with slow circular movements to cover a $1 \mathrm{sqm}$ area at heights of 0.7-2 $\mathrm{m}$. In order to minimize field perturbation by the measurer, the meter was held at arm's lengths from the investigator, with the outward extending probe. The measurements were conducted in about $0.8-0.9 \mathrm{~m}$ from the investigator. On the whole, 51 spots were measured in the square and the street area connected to the square.

The radiofrequency broadband analyser make and model was Wandell \& Goltermann EMR300, E-field probe 2244/90. The characteristics include: A resolution of $0.01 \mathrm{~V} / \mathrm{m}$; settling time typically $1 \mathrm{sec}$; displaying instantaneous measured value, maximum value and average value.

The E-field probe used had the following characteristics: A frequency range $100 \mathrm{kHz}$ to $3 \mathrm{GHz}$, measurement range 0.6 to $800 \mathrm{~V} / \mathrm{m}$, linearity 0.7 to $3 \mathrm{~dB}$ depending on the amplitude, frequency response $\pm 2.4 \mathrm{~dB}$ and isotropy deviation $\pm 1.0 \mathrm{~dB}$. At each spot, the average electric field in Volts per meter $(\mathrm{V} / \mathrm{m})$ was recorded.

An EME Spy 200 exposimeter was also used in this study. The exposimeter measures 20 predefined frequency bands, as presented in Table I. They cover the frequencies of most public RF radiation emitting devices currently used in Sweden. The exposimeter covers frequencies from 88 to $5,850 \mathrm{MHz}$. For FM, TV3, TETRA, TV4\&5, Wi-Fi 2G and Wi-Fi 5G the lower detection limit is $0.01 \mathrm{~V} / \mathrm{m}\left(0.27 \mu \mathrm{W} / \mathrm{m}^{2}\right)$; for all other bands the lower detection limit is $0.005 \mathrm{~V} / \mathrm{m}\left(0.066 \mu \mathrm{W} / \mathrm{m}^{2}\right)$. For all bands the upper detection limit is $6 \mathrm{~V} / \mathrm{m}\left(95,544 \mu \mathrm{W} / \mathrm{m}^{2}\right.$; $\left.9.5544 \mu \mathrm{W} / \mathrm{cm}^{2}\right)$. The sampling time used in this study was $4 \mathrm{sec}$ which is the fastest for the given exposimeter.
Table I. Predefined measurement frequency bands of EME Spy 200 Exposimeter Frequency ranges.

\begin{tabular}{lrr}
\hline Frequency band & $\begin{array}{r}\text { Frequency } \\
\text { MIN (MHz) }\end{array}$ & $\begin{array}{r}\text { Frequency } \\
\text { MAX (MHz) }\end{array}$ \\
\hline FM & 88 & 107 \\
TV3 & 174 & 223 \\
TETRA I & 380 & 400 \\
TETRA II & 410 & 430 \\
TETRA III & 450 & 470 \\
TV4\&5 & 470 & 770 \\
LTE 800, 4G (DL $\left.{ }^{\mathrm{a}}\right)$ & 791 & 821 \\
LTE 800, 4G (UL $)$ & 832 & 862 \\
GSM 900 + UMTS 900, 3G (UL) & 880 & 915 \\
GSM 900 + UMTS 900, 3G (DL) & 925 & 960 \\
GSM 1800 (UL) & 1,710 & 1,785 \\
GSM 1800 (DL) & 1,805 & 1,880 \\
DECT & 1,880 & 1,900 \\
UMTS 2100, 3G (UL) & 1,920 & 1,980 \\
UMTS 2100, 3G (DL) & 2,110 & 2,170 \\
Wi-Fi, 2 GHz & 2,400 & $2,483.5$ \\
LTE 2600, 4G (UL) & 2,500 & 2,570 \\
LTE 2600, 4G (DL) & 2,620 & 2,690 \\
WiMax & 3,300 & 3,900 \\
Wi-Fi 5 GHz & 5,150 & 5,850 \\
& & \\
\hline
\end{tabular}

${ }^{\mathrm{a} D L}$, down link; transmission from base station to mobile phone;

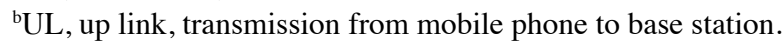

The exposimeter measures different telecommunications protocols: Frequency modulation (FM) radio broadcasting; television (TV) broadcasting; TETRA emergency services (police, rescue, etc.); global system for mobile communications (GSM) second generation mobile communications; universal mobile telecommunications systems (UMTS) third generation mobile communications, 3G; long-term evolution (LTE) fourth generation mobile communications standard, 4G; digital European cordless telecommunications (DECT) cordless telephone systems standard; Wi-Fi wireless local area network protocol; worldwide interoperability for microwave access (WIMAX) wireless communication standard for high speed voice, data and internet. The location of the mobile phone base station antenna at the square is presented in Fig. 2.

\section{Results}

Järntorget, Stockholm Old Town. The field spatial distribution measurement conducted at Järntorget square (Fig. 3) illustrates the propagation of the microwaves from the mobile phone base station's several antennas. Based on the radiofrequency broadband analyser spot measurements, the maximum E-field topped at $11.6 \mathrm{~V} / \mathrm{m}$ at the centre of the square, where the antenna is focused. The Järntorget's mean value was $5.2 \mathrm{~V} / \mathrm{m}$; median, 5.0 V/m; range, 1.2-11.6 V/m; whereas in the whole square the field level was nowhere below $2 \mathrm{~V} / \mathrm{m}$. When distancing from 


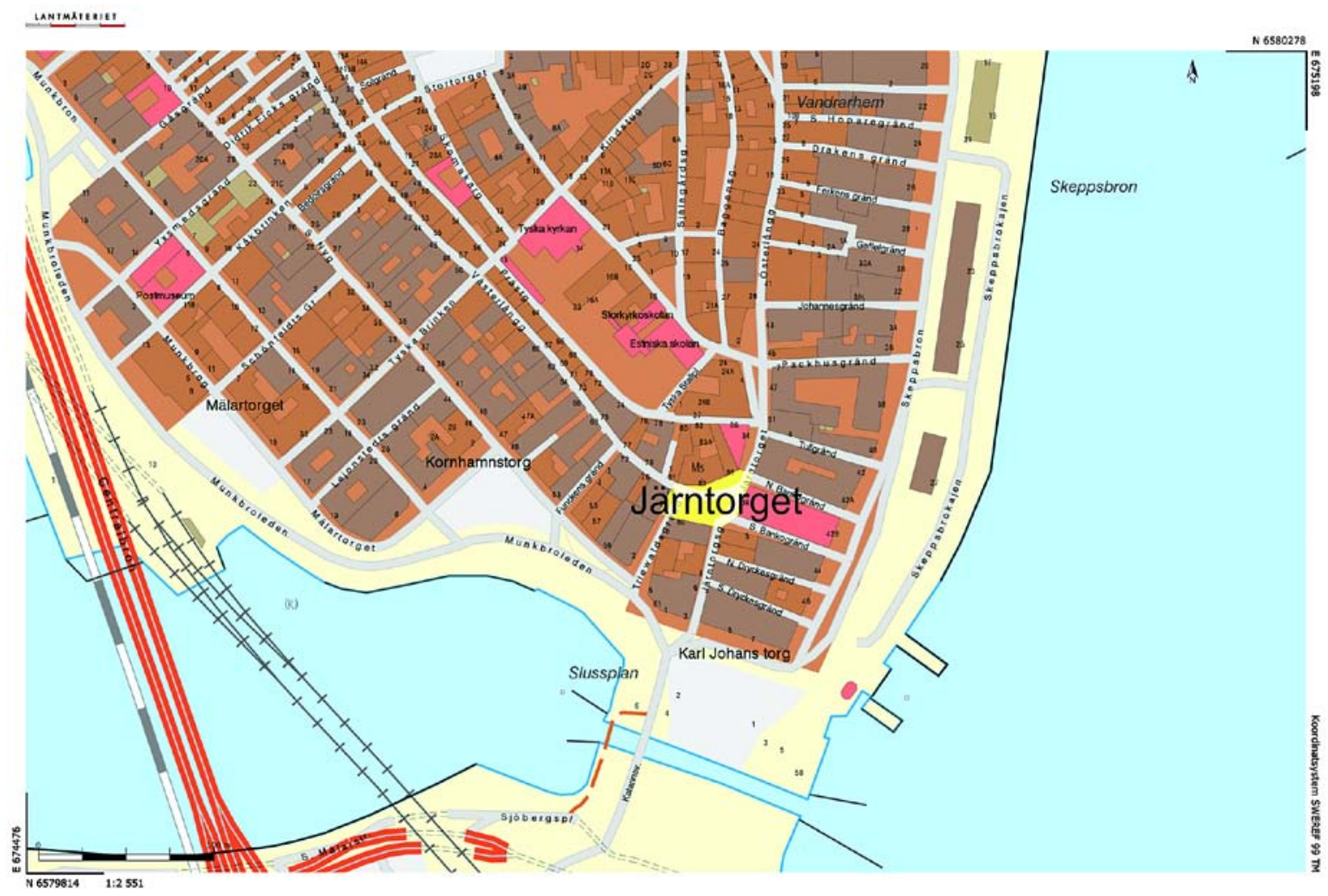

Figure 1. The map shows the location of Järntorget square in The Old Town at Stockholm city. Map from Lantmäteriet, Sweden.

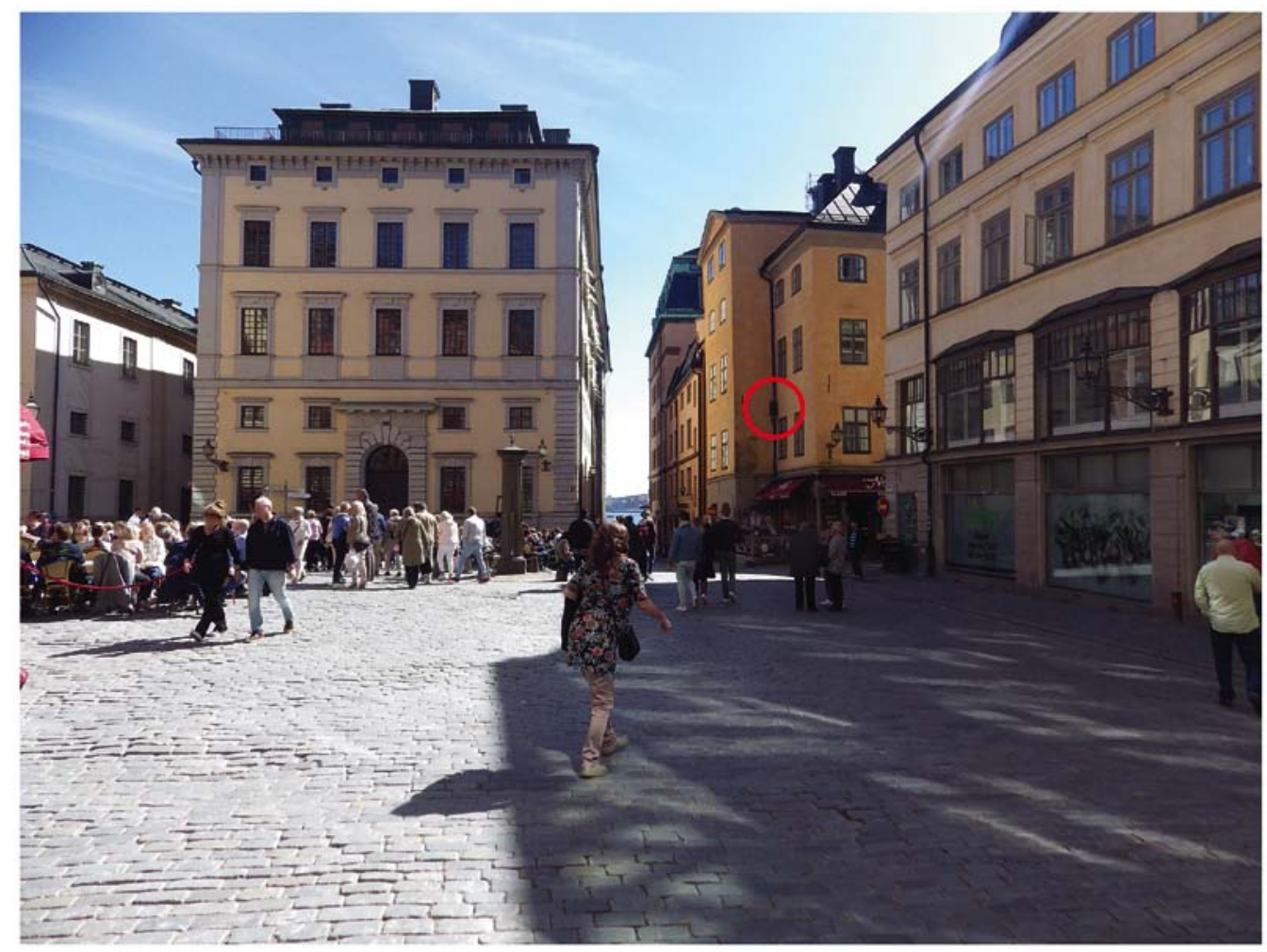

Figure 2. Järntorget square in Stockholm; the red circle indicates a mobile phone base station antenna.

the square, into the narrow streets, the field level gradually dropped; note top in figure scale $11.43 \mathrm{~V} / \mathrm{m}$.

Fig. 4 depicts different radiofrequency components at Järntorget across different communication bands. The main contributors to the radiofrequency exposure, time averaged over half an hour period, were all mobile telephony bands: LTE $2600 \mathrm{DL} 1.7 \mathrm{~V} / \mathrm{m}$, GSM+UMTS $900 \mathrm{DL} 1.6 \mathrm{~V} / \mathrm{m}$, LTE 800 DL $1.2 \mathrm{~V} / \mathrm{m}$, UMTS 2100 DL $0.9 \mathrm{~V} / \mathrm{m}$. 


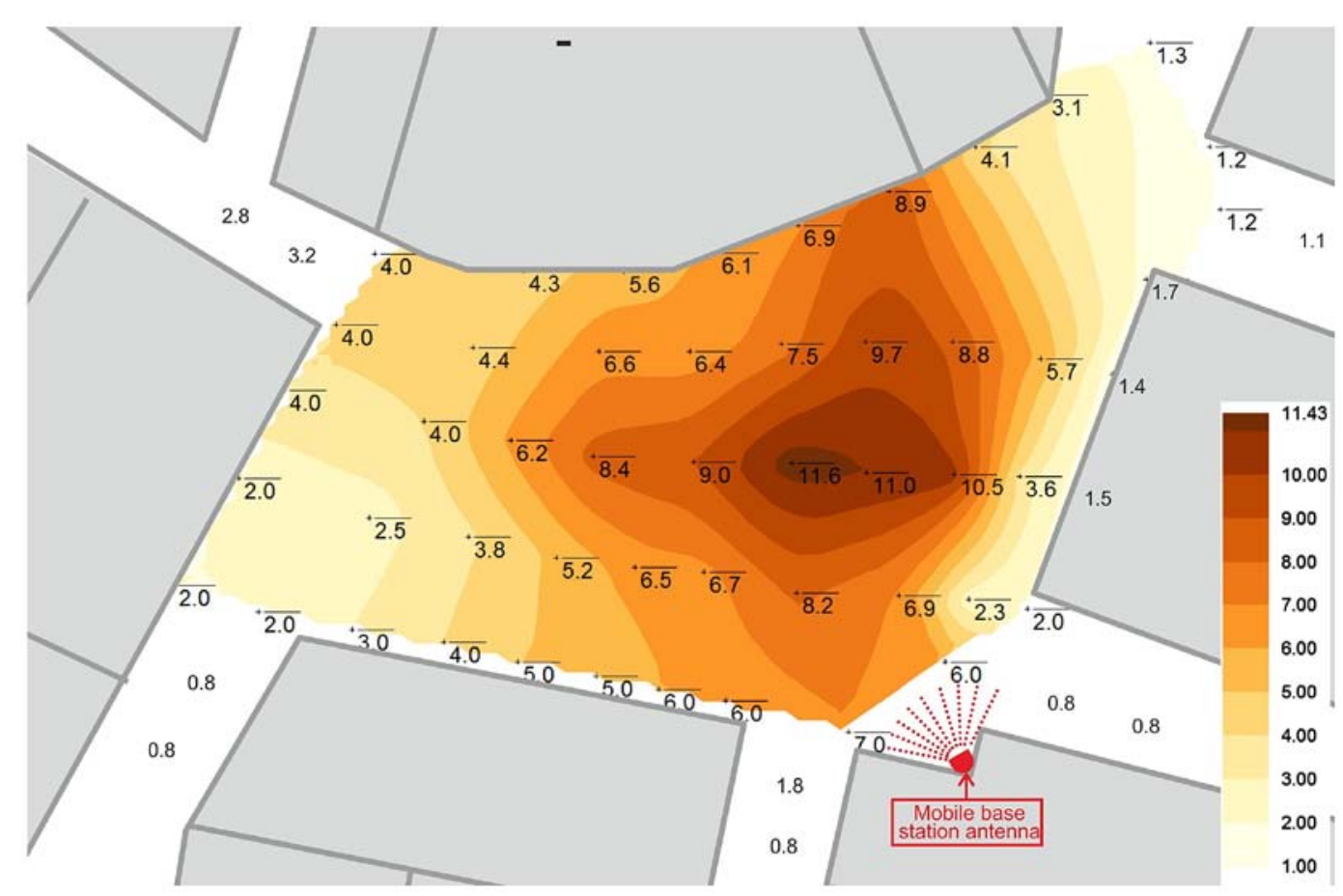

Figure 3. Järntorget square radiofrequency E-field distribution, units in Volts per meter (V/m), 5.05.2018 12:00, measured by a broadband meter (Wandell \& Goltermann EMR-300) covering $100 \mathrm{kHz}$ to $3 \mathrm{GHz}$.

\section{Discussion}

Ramazzini Institute rat study. In this lifespan carcinogenicity study, Sprague-Dawley rats were exposed to $1.8 \mathrm{GHz}$ GSM environmental radiation (17). A statistically significant increase in the incidence of malignant schwannoma in the heart was found in male rats at the highest dose, $50 \mathrm{~V} / \mathrm{m}$, corresponding to $0.66 \mathrm{~mW} / \mathrm{cm}^{2}\left(6,63 \mathrm{~W} / \mathrm{m}^{2}\right)$ and whole-body SAR of $0.1 \mathrm{~W} / \mathrm{Kg}$ (Fig. 5.)

An increased incidence of heart Schwann cell hyperplasia was observed in the treated male and female rats at the highest dose $(50 \mathrm{~V} / \mathrm{m})$, although this was not statistically significant (Fig. 6). In the treated female rats at the highest dose $(50 \mathrm{~V} / \mathrm{m})$ the incidence of malignant glial tumours was increased, although this was not statistically significant (Fig. 7). No conclusive evidence on glia cell hyperplasia was found (Fig. 8).

More prominent effects on health due to lower compared to higher RF radiation exposure have been observed in studies, which could indicate a frequency and power-window based response. This has been shown in studies with RF-radiation exposure down to peak power output of $1 \mathrm{~mW}$ from a GSM mobile phone, where the blood brain barrier opened and led to leakage into the brain tissues of large molecules, e.g., albumin and big molecules that can be toxic to brain tissue $(18,19)$. In the Ramazzini Institute study, it was shown in Figs. 7 and 8, that $25 \mathrm{~V} / \mathrm{m}$ yielded a higher incidence of glial cell hyperplasia and glia cell malignant tumours in male rats, than exposure to $50 \mathrm{~V} / \mathrm{m}$.

In this study we used a broadband meter, Wandell \& Goltermann EMR-300, covering $100 \mathrm{kHz}$ to $3 \mathrm{GHz}$ for measuring radiofrequency E-field distribution, units in Volts per meter. The measurement was done at midday on May 5 , 2018 and encompassed the Järntorget square in the Stockholm
Old Town. That place was selected since in our previous study with measurements from 2016, the Järntorget square had the highest RF radiation levels in the Old Town (see Table VI and Fig. 11 in that publication) (9).

The new spot measurements carried out in Järntorget square illustrate very high exposure levels at a popular tourist destination. The square was crowded with tourists and the local population either walking or sitting in the open-air cafés. The exposure levels in the entire square were needlessly high, as mobile communications services could be provided to subscribers in the square at orders of magnitude less power as presently used. This investigation revealed that mobile telephony service providers create unnecessary high exposure at public places, by using relatively high output power in base station antennas positioned close to people. Sufficient service coverage could be provided with much less radiation levels and carefully selected positions for base station antennas.

We measured the RF radiation at Järntorget with a mean of $5.2 \mathrm{~V} / \mathrm{m}$, a median of $5.0 \mathrm{~V} / \mathrm{m}$ and a range of $1.2-11.6 \mathrm{~V} / \mathrm{m}$. Interestingly, the mean and median levels were only one order of magnitude lower than the radiation in the RI study, $50 \mathrm{~V} / \mathrm{m}$, with a statistically significant increase in the incidence of malignant schwannoma in the heart in male rats. In the same exposure group, an increased incidence of glia cell tumours in the brain was found in female rats. Based on thermal effects, a safety factor of 10 has been used for workers and additionally one fifth of that level for individuals with increased vulnerability, such as children, those with illness and otherwise sensitive individuals yielding a specific absorption rate (SAR) of $2 \mathrm{~W} / \mathrm{kg}$ for mobile phones. This safety factor is based on acute thermal effects on the ape's eye with $100 \mathrm{~W} / \mathrm{kg}$ yielding lens clouding [see the study by Lin (20)]: 'Clearly, the motivation was to limit temperature rises inside the eye to prevent formation of lens 


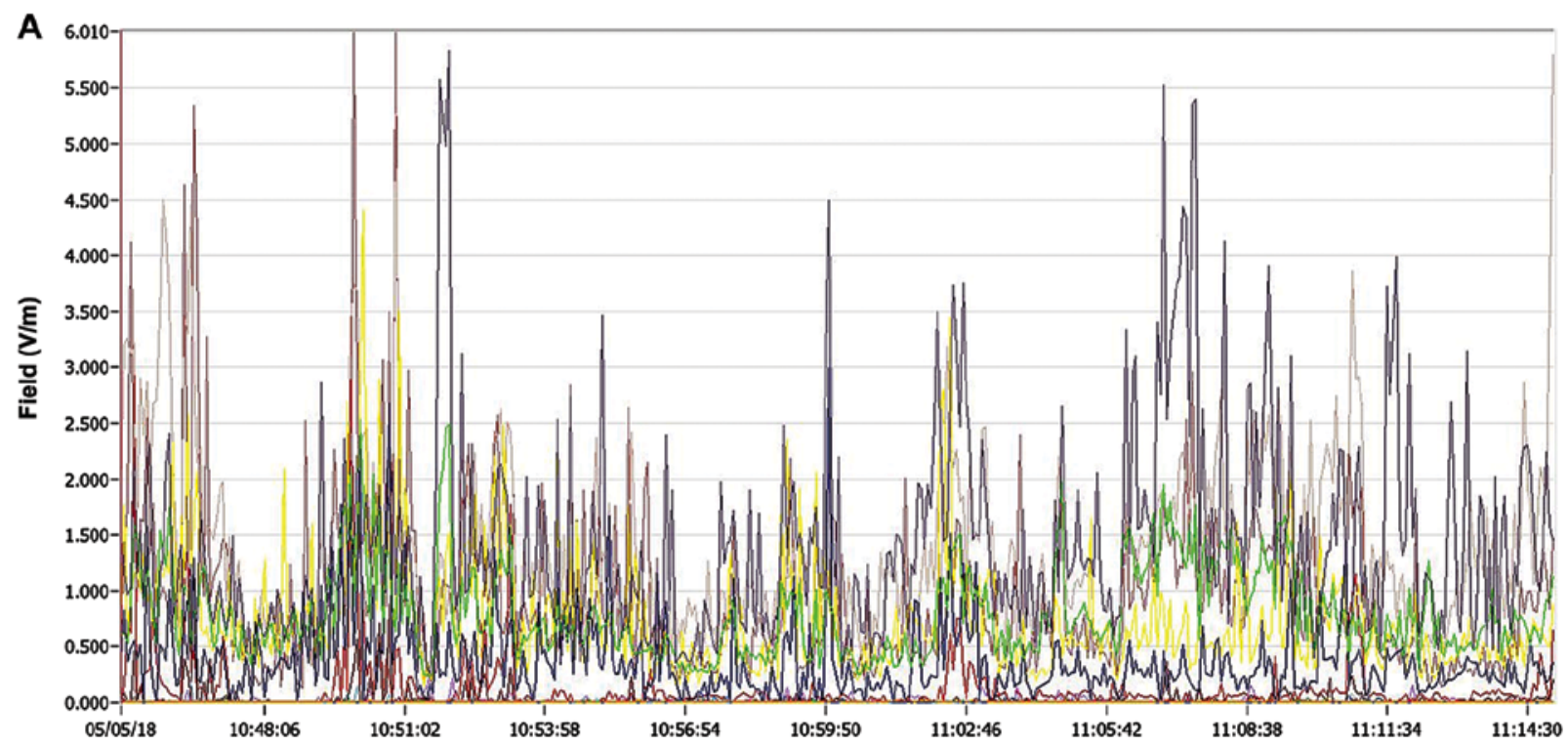

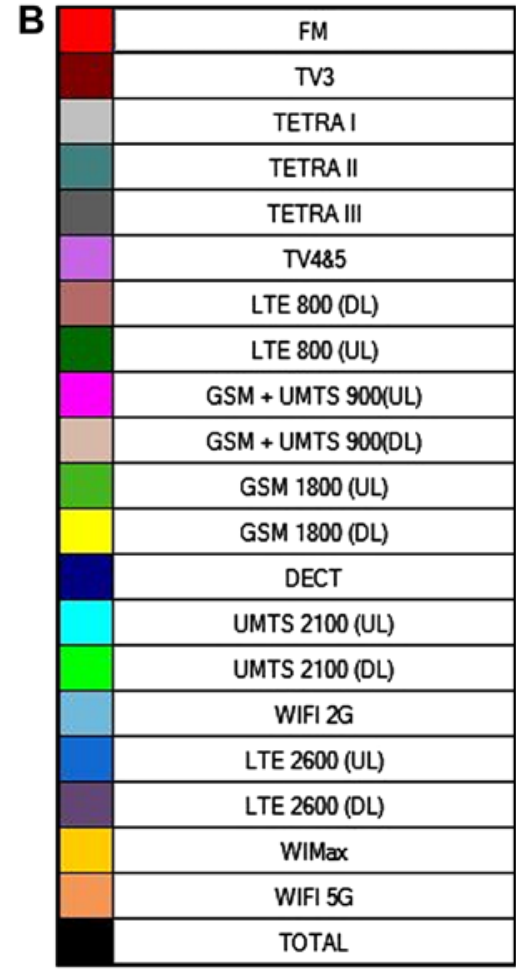

Figure 4. Radiofrequency components in Järntorget square across differen communication bands (A and B); the horizontal axis of time represents walking around the square. Same colours for the different bands are used in (A and B).

opacity-cataracts. Specifically, a safety factor of ten was applied to reduce the SAR threshold of 100 to $10 \mathrm{~W} / \mathrm{kg}$. To provide for an additional margin of safety for the general public, an extra factor of five was introduced to arrive at $2 \mathrm{~W} / \mathrm{kg}$ over $10 \mathrm{~g}$ of contiguous tissue, including the eye'. Using the same logic in safety factors as for SAR regarding the RI results would yield $2.5 \mathrm{~V} / \mathrm{m}$ as a safety level. Thus, our results at Järntorget exceed that RF radiation magnitude.

The literature on cancer risks relating to $\mathrm{RF}$ radiation from base stations is limited. A review on 10 studies up to 2009 revealed that eight of these studies showed either neurobehavioral effects or cancer in populations living $<500 \mathrm{~m}$ from a base station (21).

A review by Levitt and Lai (22) listed 56 studies. Exposure from base stations and other antenna arrays revealed changes in animals, humans and biological material in immunological and reproductive systems, as well as DNA double-strand breaks, influence on calcium movement in the heart and increased proliferation rates in human astrocytoma cancer cells.

The mean distance to base station for registered address at birth among 1,397 cancer cases aged 0-4 years during 1999-2001 and 5,588 birth controls was similar among the cases and controls (23). The total calculated power output within $700 \mathrm{~m}$ of the addresses yielded a statistically significant difference. The study had limited power to detect an increased cancer risk, since it was performed during a time period before the massive increase in ambient RF radiation from base stations, a relatively long distance to the base station and a short follow-up time.

A study from Brazil included 7,191 cancer deaths during 1996 to 2006, most of these, $93.5 \%$, within an area of $500 \mathrm{~m}$ from the base stations (24). The mortality rate decreased outside that area. The largest accumulated electric field measured was $12.4 \mathrm{~V} / \mathrm{m}$ and the lowest $0.4 \mathrm{~V} / \mathrm{m}$. The density power varied between $400 \mu \mathrm{W} / \mathrm{m}^{2}$ to $407,800 \mu \mathrm{W} / \mathrm{m}^{2}$. Our measured RF radiation levels at Järntorget were within that range.

Cancer incidence and mortality data were investigated after an alleged cancer cluster in West Midlands, UK following the installation of a mobile phone base station (25). A total of 19 persons had developed cancer, but did not fulfil criteria for cancer cluster, standardized mortality rates (SMR) for all cancer excluding non-melanoma skin cancers was for all persons 1.27 , and $95 \%$ confidence interval $(\mathrm{CI})=1.06-1.51$ during 2001-2003.

Environmental exposure to RF radiation and the risk of malignant lymphoma was investigated in a case-control study in Sardinia, Italy (26). Self-reported distance of the three longest held residential addresses for 322 cases and 


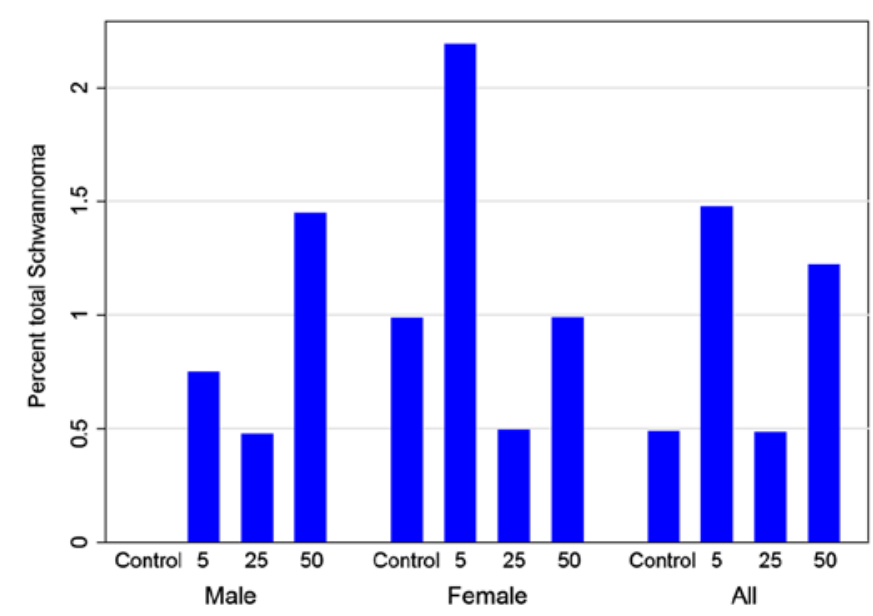

Figure 5. Total schwannoma incidence according to Table 2 in the study by Falcioni et al (17).

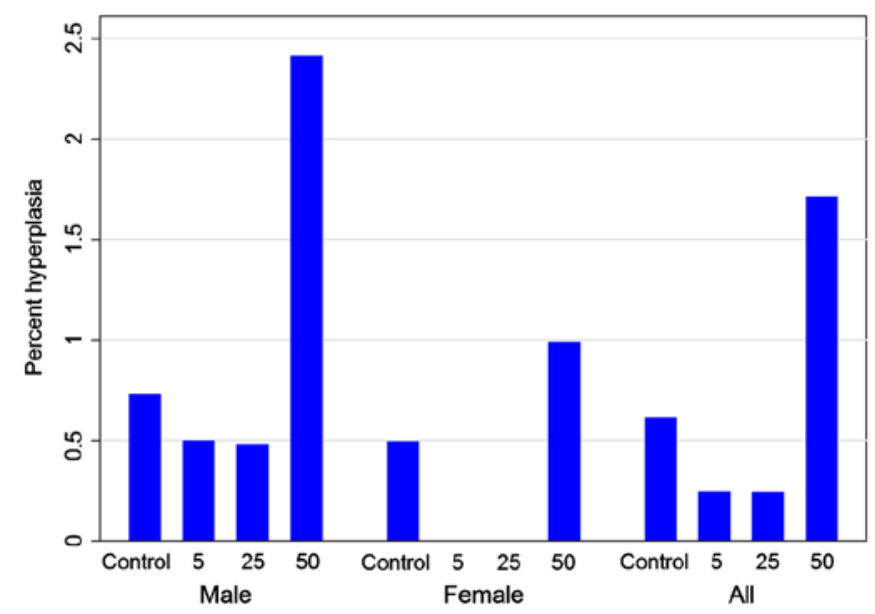

Figure 6. Schwann cell hyperplasia according to Table 2 in the study by Falcioni et al (17).

444 controls were analysed for radio-TV transmitters and base stations. In addition, some measurements of exposure were done. Residence within 50 meters to a fixed radio-TV transmitter yielded overall for lymphoma odds ratio $(\mathrm{OR})=2.7$, and $95 \% \mathrm{CI}=1.5-4.6$. For mobile base stations no association was found.

Long term studies on low exposure to RF radiation on humans have shown influence on the neurotransmitters adrenaline, noradrenaline, dopamine and phenylethylamine when a GSM $900 \mathrm{MHz}$ base station was installed in the village of Rimbach in Germany (27) and cortisol and thyroid hormones in people living near base stations $(28,29)$. The chronic dysregulation of psychobiological stress markers may contribute to health problems and chronic illnesses.

Genetic damage using comet assay in blood leucocytes was used in 63 persons residing within $300 \mathrm{~m}$ from a base station and 28 healthy controls (30). DNA migration length, genetic damage frequency and damage index were statistically significantly elevated in the sample group compared to the controls. The power density was statistically significantly higher for the cases than for the controls. The linear regression analysis revealed daily mobile phone use, location of residence

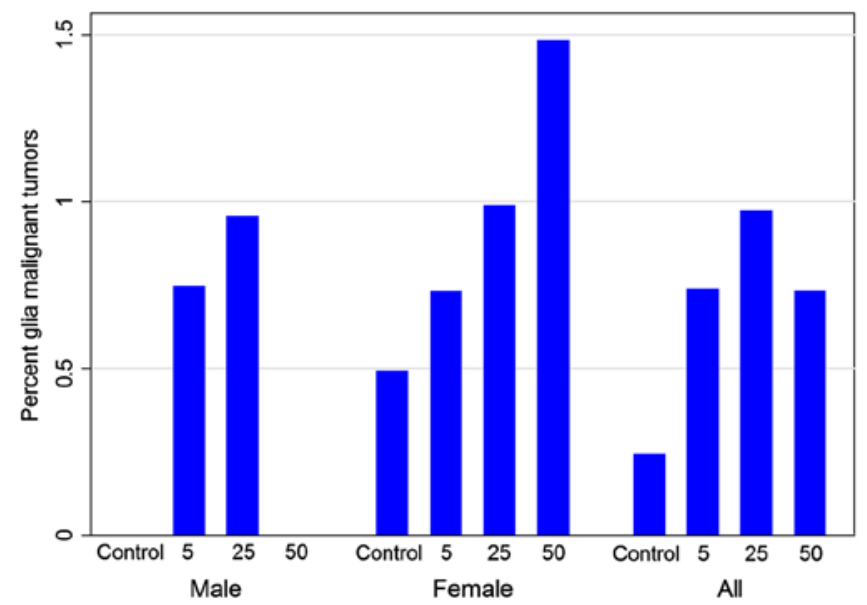

Figure 7. Glia cell malignant tumours according to Table 3 in the study by Falcioni et al (17).

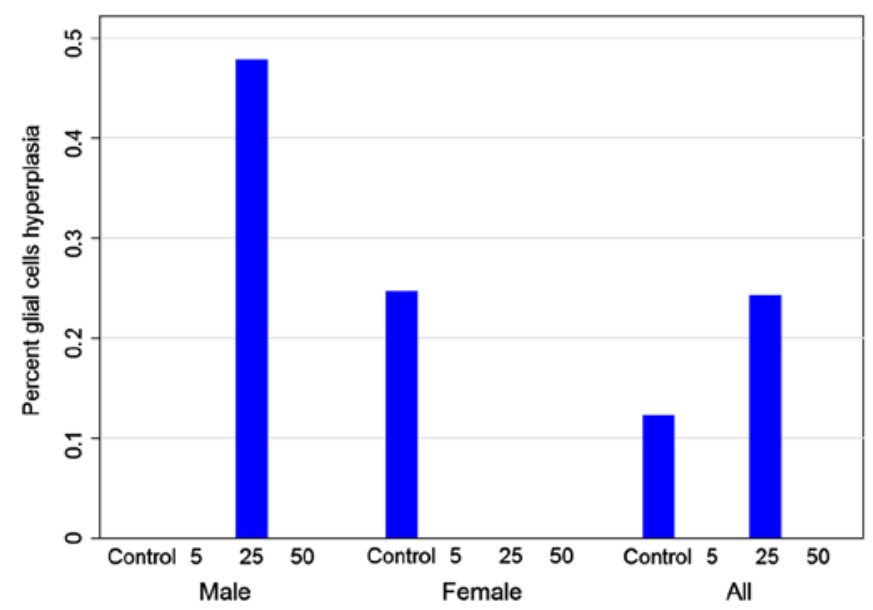

Figure 8. Glia cell hyperplasia according to Table 3 in the study by Falcioniet al (17).

and power density as statistically significant predictors of genetic damage.

DNA damage was also analysed in a study group of 40 persons residing within $80 \mathrm{~m}$ of mobile phone base stations compared with a control group living $300 \mathrm{~m}$ or more from base stations (31). Multiple linear regression analyses revealed in the exposed group statistically significantly elevated micronucleus activity and lipid peroxidation and reduced concentrations of some analysed antioxidants (glutathione, catalase and superoxide dismutase).

In conclusion, this study demonstrated RF radiation levels at one square, Järntorget, in Stockholm, Sweden one order of magnitude lower than those showing an increased incidence of tumours (schwannoma and glioma) in the RI animal study with life-long exposure to $1.8 \mathrm{GHz}$ base station environmental radiation. These results indicate that an increased cancer risk may be the situation for individuals staying at the square, primarily for those working in shops and cafés around the square. We have not measured RF radiation emissions in apartments around the square. It cannot be excluded that at certain places, the radiation may even be higher than those now measured, c.f. Hardell et al (10). 


\section{Acknowledgements}

Not applicable.

\section{Funding}

The study was supported by grants from Mr. Brian Stein, Cancerhjälpen (Stockholm, Sweden) and the PandoraFoundation for Independent Research, Berlin, Germany.

\section{Availability of data and materials}

The datasets generated and analysed during the current study are available from the corresponding author on reasonable request.

\section{Authors' contributions}

All authors participated in the conception, design and writing of the manuscript and have read and approved the final version. MC constructed all Figures based on the study by Falcioni et al (17). TK made measurements of radiofrequency radiation levels.

\section{Ethics approval and consent to participate}

Not applicable.

\section{Patient consent for publication}

Not applicable.

\section{Competing interests}

The authors declare that they have no competing interests.

\section{References}

1. Baan R, Grosse Y, Lauby-Secretan B, El Ghissassi F, Bouvard V, Benbrahim-Tallaa L, Guha N, Islami F, Galichet L and Straif K WHO International Agency for Research on Cancer Monograph Working Group: Carcinogenicity of radiofrequency electromagnetic fields. Lancet Oncol 12: 624-626, 2011.

2. IARC Monographs on the Evaluation of Carcinogenic Risks to Humans. In: Non-Ionizing Radiation, Part 2: Radiofrequency Electromagnetic Fields. Vol 102. Lyon, France: International Agency for Research on Cancer; 2013. http://monographs.iarc.fr/ ENG/Monographs/vol102/mono102.pdf. Accessed October 30, 2018.

3. Starkey SJ: Inaccurate official assessment of radiofrequency safety by the Advisory Group on Non-ionising Radiation. Rev Environ Health 31: 493-503, 2016.

4. Hardell L: World Health Organization, radiofrequency radiation and health - a hard nut to crack (Review). Int J Oncol 51: 405-413, 2017.

5. The 5G appeal: Scientists and doctors warn of potential serious health effects of 5G. http://www.5gappeal.eu/scientists-anddoctors-warn-of-potential-serious-health-effects-of- $5 \mathrm{~g} /$. Accessed October 30, 2018.

6. Törnevik C: Impact of EMF limits on 5G networkr oll-out ITU Workshop on 5G, EMF \& Health, Warsaw, December 5th 2017. https://www.itu.int/en/ITU-T/Workshops-andSeminars/20171205/Documents/S3_Christer_Tornevik.pdf. Accessed October 30, 2018.

7. Belpomme D, Hardell L, Belyaev I, Burgio E and Carpenter DO: Thermal and non-thermal health effects of low intensity nonionizing radiation: An international perspective. Environ Pollut 242: 643-658, 2018
8. Hardell L, Koppel T, Carlberg M, Ahonen M and Hedendahl L: Radiofrequency radiation at Stockholm Central Railway Station in Sweden and some medical aspects on public exposure to RF fields. Int J Oncol 49: 1315-1324, 2016.

9. Hardell L, Carlberg M, Koppel T and Hedendahl L: High radiofrequency radiation at Stockholm Old Town: An exposimeter study including the Royal Castle, Supreme Court, three major squares and the Swedish Parliament. Mol Clin Oncol 6: 462-476, 2017.

10. Hardell L, Carlberg M and Hedendahl LK: Radiofrequency radiation from nearby base stations gives high levels in an apartment in Stockholm, Sweden: A case report. Oncol Lett 15: 7871-7883, 2018.

11. Carlberg M, Hedendahl LK, Koppel T and Hardell L: High ambient radiofrequency radiation in Stockholm city, Sweden. Oncol Lett (In press).

12. National Toxicology Program: NTP technical report on the toxicology and carcinogenesis studies in Hsd:Sprague Dawley sd rats exposed to whole-body radio frequency radiation at a frequency (900 MHz) and modulations (GSM and CDMA) used by cell phones. NTP TR 595, March 26-28, 2018. https://ntp.niehs.nih.gov/ ntp/about_ntp/trpanel/2018/march/tr595peerdraft.pdf. Accessed October 30, 2018.

13. National Toxicology Program: NTP technical report on the toxicology and carcinogenesis studies in $\mathrm{B} 6 \mathrm{C} 3 \mathrm{~F} 1 / \mathrm{N}$ mice exposed to whole-body radio frequency radiation at a frequency $(1,900 \mathrm{MHz})$ and modulations (GSM and CDMA) used by cell phones. NTP TR 596, March 26-28, 2018. Available from: https://ntp.niehs. nih.gov/ntp/about_ntp/trpanel/2018/march/tr596peerdraft.pdf. Accessed October 30, 2018.

14. Hardell L and Carlberg M: Comments on the US National Toxicology Program technical reports on toxicology and carcinogenesis study in rats exposed to whole-body radiofrequency radiation at $900 \mathrm{MHz}$ and in mice exposed to whole-body radiofrequency radiation at 1,900 MHz. Int J Oncol: 54: 111-127, 2019.

15. Hardell L, Carlberg M, Söderqvist F and Mild KH: Pooled analysis of case-control studies on acoustic neuroma diagnosed 1997-2003 and 2007-2009 and use of mobile and cordless phones. Int J Oncol 43: 1036-1044, 2013.

16. Carlberg $\mathrm{M}$ and Hardell L: Evaluation of mobile phone and cordless phone use and glioma risk using the Bradford Hill viewpoints from 1965 on association or causation. BioMed Res Int 2017: 9218486, 2017

17. Falcioni L, Bua L, Tibaldi E, Lauriola M, De Angelis L, Gnudi F, Mandrioli D, Manservigi M, Manservisi F, Manzoli I, et al: Report of final results regarding brain and heart tumors in Sprague-Dawley rats exposed from prenatal life until natural death to mobile phone radiofrequency field representative of a $1.8 \mathrm{GHz}$ GSM base station environmental emission. Environ Res 165: 496-503, 2018.

18. Nittby H, Brun A, Eberhardt J, Malmgren L, Persson BR and Salford LG: Increased blood-brain barrier permeability in mammalian brain 7 days after exposure to the radiation from a GSM-900 mobile phone. Pathophysiology 16: 103-112, 2009.

19. Eberhardt JL, Persson BR, Brun AE, Salford LG and Malmgren LO: Blood-brain barrier permeability and nerve cell damage in rat brain 14 and 28 days after exposure to microwaves from GSM mobile phones. Electromagn Biol Med 27: 215-229, 2008.

20. Lin JC: Safety standards for human exposure to radio frequency radiation and their biological rationale. IEEE Microw Mag 4: 22-26, 2003.

21. Khurana VG, Hardell L, Everaert J, Bortkiewicz A, Carlberg M and Ahonen M: Epidemiological evidence for a health risk from mobile phone base stations. Int J Occup Environ Health 16: 263-267, 2010.

22. Levitt BB and Lai H: Biological effects from exposure to electromagnetic radiation emitted by cell tower base stations and other antenna arrays. Environ Rev 18: 369-395, 2010.

23. Elliott P, Toledano MB, Bennett J, Beale L, de Hoogh K, Best N and Briggs DJ: Mobile phone base stations and early childhood cancers: Case-control study. BMJ 340: c3077, 2010.

24. Dode AC, Leão MM, Tejo FA, Gomes AC, Dode DC, Dode MC, Moreira CW, Condessa VA, Albinatti C and Caiaffa WT: Mortality by neoplasia and cellular telephone base stations in the Belo Horizonte municipality, Minas Gerais state, Brazil. Sci Total Environ 409: 3649-3665, 2011.

25. Stewart A, Rao JN, Middleton JD, Pearmain P and Evans T: Mobile telecommunications and health: Report of an investigation into an alleged cancer cluster in Sandwell, West Midlands. Perspect Public Health 132: 299-304, 2012. 
26. Satta G, Mascia N, Serra T, Salis A, Saba L, Sanna S, Zucca MG, Angelucci E, Gabbas A, Culurgioni F, et al: Estimates of Environmental Exposure to Radiofrequency Electromagnetic Fields and Risk of Lymphoma Subtypes. Radiat Res 189: 541-547, 2018.

27. Buchner $\mathrm{K}$ and Eger $\mathrm{H}$ : Changes of clinically important neurotransmitters under the influence of modulated RF fields-A long-term study under real-life conditions. Umwelt-MedizinGesellschaft 24: 44-57, 2011 (In German).

28. Augner C, Hacker GW, Oberfeld G, Florian M, Hitzl W, Hutter J and Pauser G: Effects of exposure to GSM mobile phone base station signals on salivary cortisol, alpha-amylase, and immunoglobulin A. Biomed Environ Sci 23: 199-207, 2010.

29. Eskander EF, Estefan SF and Abd-Rabou AA: How does long term exposure to base stations and mobile phones affect human hormone profiles? Clin Biochem 45: 157-161, 2012.
30. Gandhi G, Kaur G and Nisar U: A cross-sectional case control study on genetic damage in individuals residing in the vicinity of a mobile phone base station. Electromagn Biol Med 34: 344-354, 2015.

31. Zothansiama ZM, Zosangzuali M, Lalramdinpuii $\mathrm{M}$ and Jagetia GC: Impact of radiofrequency radiation on DNA damage and antioxidants in peripheral blood lymphocytes of humans residing in the vicinity of mobile phone base stations. Electromagn Biol Med 36: 295-305, 2017.

(i) (9) This work is licensed under a Creative Commons Attribution-NonCommercial-NoDerivatives 4.0 International (CC BY-NC-ND 4.0) License. 